\title{
Improving the Students' Ability in Reading Comprehension by Using Cooperative Integrated Reading Composition
}

\author{
Rohdearni Wati Sipayung \\ Dosen FKIP Universitas Simalungun, Indonesia \\ dearsipayunk@gmail.com
}

\begin{abstract}
This research objective is to find out the student's ability in reading comprehension by using CIRC. The population was the first grade students of SMP Swasta Cinta Rakyat 1 Melanthon Siregar Pematangsiantar.The research design was used classroom action research. To collect the data, the researcher uses test that consist of pre test and post test that is formed of multiple choice. In analyzing the data the researcher uses theory from Harris, A. J (1984) and Arikunto, S (2007). Based on analyzing the data, the researcher found that mean score of the students in pre-test is 40,66 and mean score from post test is 73,33. From the score in pre test and post test, the researcher can seen the significant improvement score of the students. Based on the result of the research, the researcher can suggest that the CIRC method is the effective method to teach reading especially in reading comprehension a text.
\end{abstract}

Keywords : reading comprehension; cooperative learning; CIRC

\section{Introduction}

English is an international language. As an international language, English has some basic skills. There are four skills in English, they are listening, speaking, reading and writing. Reading is the most important thing in the human life. It is because by the reading people can get all of the information that they need. Besides, by the reading, people also can increase their knowledge. So, there is proverb that has said" Reading is the window of the world."

In the school, teaching reading to the students is needed because all of the activities that the students' do in their classrooms are reading. For example, the teacher gives the materials to the students from the students' handbook. So, if the students want to understand about the lesson well, they must have a reading skill. The other example such as, if the students have a task from their teacher, they should be read their handbook or the other sources like articles, magazine, etc to search the answer of the task. So in this case they should be have the reading skill also.

Nowadays, we have seen that many of students can read a text, but they can't understand what the text is about. The researcher observed that the students ability in reading comprehension a text in SMP Swasta Cinta Rakyat 2 Pematangsiantar still low. It can be seen from there are only a few students have a good achievement but the others still below of average.

The problem happened because some reasons. First, students have the minimum of vocabulary. The second, the students can't different the tenses and the last mother language of the students still strong in themselves so they have difficult to learn the foreign language. Besides, teaching reading comprehension is not easy. Some students perceive reading is bored. The boredom can make them doesn't follow the lesson anymore. In, this situation the teacher should be able to choose the best and fun method to teaching reading comprehension to the students. Such a phenomenon, it is necessary to use an appropriate method to enhance students' reading ability, in this case is Cooperative Integrated Reading Composition (CIRC). 


\section{Review of Literature}

\subsection{Definition of Reading}

There are four skills in English such as reading, writing, listening and speaking. Reading is one of important thing in the human life. Because, reading can make the people know about all of the information in the World. In the school, the students should be developed their reading skill. It is because if the students want to be a good student, they should be read the books more and more. So, a reading skill very needed in this case.

According to Tarigan (2005:7), he defines reading as a process that is done and used by readers in order to get messages that will be present by writer through words or written form. In addition, Nuttal (1996:3) says reading is the transfer of a message from the writer to reader. Based on the explanation above, it can be conclude that reading is the process of to get message or information from the writer to reader through words or written form.

Reading comprehension consist of two words, they are reading and comprehension. We have known that reading is the process of to get message or information from the writer to reader. Comprehension refers to the ability to understand. In order word, it is stated comprehension is the capacity of the mind to perceive and understand. Comprehension also is the essence of reading because the goal of written language is communication of messages. If we do not understand the message, we are not reading. Burns (1990:151) states that the basic comprehension units in reading are words, sentences, paragraph and selection.

Based on the definition of reading and comprehension above, Grellet (1992:3) state that reading comprehension is understanding a written text and extracting the required information from it as efficiently as possible.

Based on the explanation above, it will be calculated that reading comprehension is the ability to understand of a written text or passage to get information or message that transfer from the writer to the reader.

\subsection{Definition of Cooperative Learning}

Cooperative learning has been suggested as the solution ro wide array of educational problems. It is often cited as a means of emphasizing thinking skills and increasing higherolder learning, as an alternative to ability grouping, remediation, or special education, as a means of improving race relations and as a way to prepare students for an increasingly collaborative work face.

Cooperative learning is an instructional program in which students work in small groups to help one another master academic content (Slavin, 1995). Cooperative learning involves students working together in pairs or groups, and they share information .They are a team whose players must work together in order to achieve goals successfully. Richard and Renandya (2002:52) states that cooperative learning is more than just putting students in groups and giving something to do.

From the explanation above, it can be concluded that cooperative learning is the method of teaching that giving facilities to students to respect with each other to solve the problem by group working.

There are many quite different forms of cooperative learning, but all of them involve having students work in small group or teams to help one another learn academic material. Cooperative learning methods fall into two main categories, they are: 
- Structured team learning involves rewards to teams based on the learning progress of their members, and they are also characterized by individual accountability, which means that tea success depend on individual learning, not group products.

- Informal group learning methods covers methods more focused on social dynamic, projects, and discussion than on mastery pf well-specified content.

\subsection{Cooperative Integrated Reading Composition (CIRC)}

A comprehensive program for teaching reading and writing in the upper elementary grades is called cooperative integrated reading composition (CIRC) (Sevens et al. 1987). Steven and Slavin in Nur (2000: 8) state that CIRC is a technique where the students' work in their teams on a variety of cooperative activities including partner reading, identification of main story elements, vocabulary and summarization activities, practice of reading comprehension strategies, and creative writing using a process writing approach. To this study this technique is focused on the learning system where the students' work together in a working group.

In cooperative integrated reading and composition (CIRC), teachers use basic reading texts and traditional reading groups but assign pairs of students from different reading groups to meet and work on specialized tasks. For instance, students in the pairs might read to each other, make predictions about the reading, summarize stories, and work on vocabulary skills.

To applying the method of CIRC, there are some step that the teachers to do in classroom, such as:

1. Preparing the material that will be used in teaching learning process.

2. Warming up the class and giving some question to the students appropriate with the topic.

3. Asking the students to make a group consist of four to five persons in each group. Here they will work together to learn about the material.

4. Giving a text to each of groups.

5. Explaining some points of the materials if the students face difficulties

6. Asking each of groups to present or read the result of their discussion in front of the class.

7. Giving evaluated and conclusion about the material.

\section{Research Methodology}

In this research, the researcher use classroom action research. According to Dave Ebbutt (1985) action research is about the systematic study of attempts to improve educational action and by means of their own reflection upon the effects of those actions.

Population is all of particular in the group that will be researched. According to Suharsini Arikunto (2006:130), population is the subject of research. The population of this research is the first grade students of SMP Swasta Cinta Rakyat 1 Pematangsiantar which consist of 30 students and only there is one class in the first grade.

Sample is part of population. According to Arikunto (2002:220), he states that if the research subject is less than 100 , it is better to take all., while if the research subject is more than 100 , it is better to take $10 \%-15 \%$ or $20 \%-25 \%$. 
Based on the explanation above, there are 30 of students in SMP Swasta Cinta Rakyat 1 Pematangsiantar (less than 100), so here the researcher take all the students as the sample of the research.

In this research procedure, the researcher use Elliot models modified by Hopkins. The steps implemented in Elliot model are :

1. Planning

In the planning, the researcher has done activities, such as preparing the series of the text and also preparing students work exercises.

2. Action

In this phase, the researcher gives pre-test to the students, after that the researcher gives the material to the students. Here, the researcher focuses on improvement students 'ability in reading comprehension by using CIRC. And the last the researcher give the post-test to the students to know the improvement of their reading comprehension.

3. Observing

In observing, the researcher will observe the students whether the students are focus and understand about the material or not.

4. Reflecting In reflecting, it is time to the researcher to analyze and evaluate the students work in classroom. In technique of collecting data, the researcher use technique of test to know the students achievement in reading comprehension.

Data were very crucial to achieve the successful of the research. Test is one of the ways to collect the data. According to Brown (2003: 3) test is a method of measuring a person's ability, knowledge, or performance in a given domain. In this research, the researcher use pretest and post-test to measure the students' ability in reading comprehension. Pre-test conducted before the material given by the researcher to know the students basic ability in reading comprehension. The forms are multiple choices which consist of 10 questions. Posttest is doing by the researcher in the end of the lesson to measure the students' ability after pre-test. Post-test has the same question and same form with the pre-test. It is because, the researcher want to saw the improvement of the student's ability after applying the CIRC method. In this test, the researcher will give narrative text with the title of the text is "The Smartest Parrot". This test is taken on May, 23th 2015 from http//englishahkam.blogspot.com/2012/07/contoh-narrative-text-beserta-soal-dan_21.html.

In technique of analyzing data, the researcher use quantitative data. For the first the researcher will analyze the score of the students. To measure the score of students, the researcher uses formula by Harris (1984, p.140). The formula to measure the score is:

$$
\mathrm{S}=\frac{C}{N} \times 100
$$

Where:

$\mathrm{S} \quad=$ The score of each student

$\mathrm{C} \quad=$ The number of correct answer

$\mathrm{N} \quad=$ The number of test items.

There are 10 questions for the test. So here, the possible maximum score is 100 and the possible minimum score is 0 .

After the researcher knowing the score of the students, the researcher will give the level of achievement to the students. To make the level of achievement, the researcher follows the step from Suharsini Arikunto. In Suharsini Arikunto's book with the title "Manajemen 
Penelitian", he said that before give the predicate to the students, the researcher for the first must create the criteria of the score, and after that the categories of the score can apply by this criteria such as: excellent, good, fair, less, and poor.

So, in this research, the researcher will make the categories or level of achievement such as below:

Table 3.1 Level of Achievement

\begin{tabular}{|cc|}
\hline The Value of the Score & Level of Achievement \\
\hline $81-100$ & Excellent \\
$61-80$ & Good \\
$41-60$ & Fair \\
$21-40$ & Less \\
$0-20$ & Poor \\
\hline
\end{tabular}

And the last, to measure and check the improvement of students' ability in reading comprehension by using CIRC, the researcher use mean formula. The formula to do analyze is:

Where:

$$
\bar{X}=\frac{\sum X}{N}
$$

$\bar{X} \quad=$ Mean ( The average of the student score)

$\sum X \quad=$ The sum of item

$\mathrm{N} \quad=$ The number of the student score.

(Source: Arikunto, S. 2007. Manajemen Penelitian. Jakarta: PT. Rineka Cipta)

After all of done, the researcher will compare the result of the students between pretest and post-test.

\section{Discussion}

In doing the research to collect the data for analyzing, the researcher follow this step:

\section{Plannning}

Before the researcher do the research, the researcher have done the material about the narrative text and also the example. The researcher also have done the students work exercises for students in pre-test and post-test.

\section{Action}

In this phase, there are some steps that the researcher do. They are:

a. The researcher introduce herself to the students and explain to the students what for he stand up in the class

b. The researcher warming up the class

c. The researcher do the pre-test to the students. In this phase, the researcher gives the students work exercise to the students and ask the students to answer the question by themselves.

d. After that, the researcher collecting the data and than give the treatment to the students. The researcher explain about the narrative text to the students as well as the generic structure, social function, language feature and also the example. 
In the treatment the researcher give the example of "Snow White". It is because the story of snow white is familiar with the students.

e. After getting the treatment the researcher applying the method of CIRC. The researcher do some steps, such as asking the students to make a group consist of five persons in each group. Here they will work together to learn about the material, giving the text and exercise that same with the pre-test, explaining some points of the materials if the students face difficulties, asking each of groups to present or read the result of their discussion in front of the class, giving evaluated and conclusion about the material.

f. After applying the CIRC method, the researcher gives the post test to the students. Post test have the same question in the pre-test and grouping work exercise.

\section{Observation}

In observation, the researcher is monitoring the students' pre-test, grouping team, and post-test. When pre-test going on, the researcher observe that the students have many difficulties in answering the question. Condition of the class is very noisy because the students tried to cited with their friends. In grouping team appropriate with applying the method of CIRC, the researcher observes that there are some good things that doing by the students. The relation of the students to answering the question is so good. They change the information each other. And in the post-test, the researcher observes the condition of the class is so relax. The noisy of the students is less. The students tried to answer the question by themselves.

\section{Reflection}

Here, the researcher analyzes the test that have done by the students and evaluated them.

In this research, the researcher will describe the result or the finding of the research that have done by the researcher in SMP Swasta Cinta Rakyat 1 Pematangsiantar with the title "improving the students' ability in reading comprehension by using cooperative integrated reading composition (CIRC)". Such as that has explained in the chapter III, the researcher collects the data using pre-test and post-test. So, here the researcher will describe the result both of pre-test and post-test one by one.

\section{Conclusion}

Based on the finding of the research in the Chapter IV, the researcher can make the conclusion as follow: Using CIRC method, reading comprehension of the students in SMP Swasta Cinta Rakyat 1 Pematangsiantar has the significant improvement. Based on the result, the mean score of pre-test before giving the CIRC method is 40,66. After giving the method of CIRC in the post-test the mean score of the students is higher. It is 73,33. It means that the CIRC method has the influence to improve the students'ability in reading comprehension of the text. 


\section{References}

Arikunto, S. (2002). Prosedur Penelitian Suatu Pendekatan Praktik. Jakarta: PT.Rineka Cipta . (2006). Manajemen Penelitian. Jakarta: PT. Rineka Cipta (2007). Manajemen Penelitian. Jakarta: PT. Rineka Cipta

Block, Cathy Collins.(2004). Comprehension Process Instruction. New York: The Guilford Press

Brown, H. (2003). Principles of language learning and teaching. London:Longman

Burns, Roe, Ross. 1990. Teaching Reading in today's Elementary School: Third Edition. Houghton: Mifflin

Byram, M. (2004). Genre and genre-based teaching. The Routledge Encyclopedia of Language Teaching and Learning (pp. 234-237).

London: Routledge in Modul: Program Pendidikan dan Latihan Guru (PLPG) 2013

Grabe \& Staller. (2002). Teaching and Researching Reading, Harlow (UK), Longman ( Applied Linguistic In Action Series), p.291

Grallet, F. (1981). Developing Reading Skills. Cambridge University Press . (1992). Developing Reading Skills. Cambridge University Press

Harmer, Jeremy. (2000). The Practice of English Language Teaching. Cambridge: Longmann

Harris, A. J. 1984. How to Increase Reading Ability: A Guide to Developmental Reading. Cambridge: Cambridge University Press

McNiff, J. (1999). Action Research: Principles and Practice. London: Routledge

Mohamad, Akmar. (1990). What Do We Test When We Test Reading Comprehension. The Internet TESL Journal, 5(12). Available at http://iteslj.org/Techniques/Nunn.interacting.html

Nation, I.S.P. (2009). Teaching ESL/EFL Reading and Writing. New York: Rouledge

Nuttal, Christine. (1996). Teaching Reading Skill in a Foreign Language. Heincemann: The Path Press

PLPG, Tim Penyusun. 2013. Modul Program Pendidikan dan Latihan Profesi Guru (PLPG): Bahasa Inggris. Pematangsiantar: Universitas HKBP Nommensen Rayon 133

Richard, Jack and Renanya., Willy, A. 2002. Methodology in Language Teaching. An Anthology of Curreige Univernt Practice, New York: Cambrigy Prcite Univercity Press

Shoimin, A. (2014). 68 Model Pembelajaran Inovatif dalam Kurikulum 2013. Yogyakarta: Ar-Ruzz Media

Slavin, R. (1995). Cooperative learning: Theory, research, and practice. Massachusetts: Allyn and Bacon

Steven R.J., et al. (1987)., "Co-operative Integrated Reading and Composition: Two field experiments". Reading Research Quarterly, Vol. 22, No. 4, pp.433-454

Tarigan, Henry Guntur. 2005. Membaca sebagai Suatu Keterampilan Berbahasa. Bandung: PT.Angkasa

\section{Website:}

http//englishahkam.blogspot.com/2012/07/contoh-narrative-text-beserta-soaldan_21.html. accessed on $23^{\text {rd }}$ May 2015 